\title{
Možnosti využití fuzzy teorie pro posuzování úrovně motorických schopností
}

\section{Possibilities of Aplication Fuzzy Logic for Evaluation of Level of Motor Abilities}

\author{
Ondřej Hubáček, Jiř̌́ Zháněl
}

Fakulta tělesné kultury, Univerzita Palackého v Olomouci

\begin{abstract}
Abstrakt
Od devadesátých let minulého století se v oblasti diagnostiky pohybových činností objevují publikace využivajici teorii fuzzy logiky, která nabizi kvalitativnějiný prístup k analýze dat než klasický pravděpodobnostní prístup. Cílem práce bylo vytvoření postupu pro hodnoceni jednotlivých testů testové baterie TENDIAG1 na principu fuzzy teorie. Na základè obdobných publikovaných výzkumů a expertního posouzení jsme zkonstruovali funkce př́slušnosti kjednotlivým testům a navrhli algoritmus pro výpočet hraničních bodi̊. Postup při konstrukci funkci př́slušnosti je demonstrován na výzkumných datech souboru tenistů ve věku 11-12 let $(n=187)$, konkrétni vyhodnocení výsledkỉ bylo realizováno u subsouboru náhodnè vybraných tenistù $(n=25)$ $z$ uvedeného souboru. Pro finální vyhodnocení výsledků testové baterie jsme využili metodu agregace dillčich výsledkủ. Tento postup umožňuje jemnějši rozlišení úrovně výkonnosti jednotlivých hráčù než dosud uživaná třistupňová norma. Do budoucna lze počitat s využitím sofistikovanějšich metod agregace umožňujicí pracovat s různými vahami dilčich testů.
\end{abstract}

\begin{abstract}
Since the 90s of the twentieth century, the sports diagnostics have started applying principles of fuzzy logic, which offers a different quality approach to data analyses than the standard probability approach. The aim was to create a process for evaluating each test of the battery of tests TENDIAG1 on the principle of fuzzy theory. Based on similar published research and expert reviews we constructed membership functions for individual tests and proposed an algorithm to calculate the boundary points. Procedure for the construction of membership functions is demonstrated in the research data set of the tennis players aged 11-12 years $(n=187)$, specific evaluation of the results was performed at the sub-set of randomly selected tennis players $(n=25)$ of the set. For the final evaluation of the results of the test battery we used the method of aggregation of partial results. This procedure allows a finer resolution level of performance of individual players than the currently used threelevel standard. We are sure that in the future, more sophisticated methods of aggregation will be used, allowing to work with different weights of subtests.
\end{abstract}

Klíčová slova: diagnostics, membership function, fuzzy sets, tennis, test battery

Keywords: diagnostika, funkce př́slušnosti, fuzzy množiny, tenis, testová baterie

\section{ÚVOD}

Teorie fuzzy množin se dlouhodobě uplatňuje v různých oborech lidské činnosti, zejména pak v oborech, kde neurčitost a nejistota hrají významnou roli v rozhodovacích procesech (průmysl, ekonomie, bankovnictví, personalistika, aj.). Teorie fuzzy množin je principiálně založena na „mlhavých“ nebo „neurčitých“ hranicích svých množin a na nekonečně hodnotové logice. Funkce př́slušnosti, která přiřazuje hodnocení při přechodu mezi úrovněmi, je po částech lineární funkce (obecně to může být libovolná spojitá funkce), a tak nedochází ke „skokům“ v hodnocení jako u klasické metody s „ostrými“ čísly.

Od devadesátých let minulého století se objevují aplikace fuzzy teorie i v oblasti sportovní diagnostiky. $\mathrm{V}$ našem př́íspěvku se zabýváme možností implementace teorie fuzzy množin do hodnocení úrovně 
výkonnostních předpokladů v tenise.

\section{Syntéza poznatků}

Základy teorie fuzzy množin byly položeny v roce 1965 profesorem Zadehem. Od té doby se tato teorie dočkala řady významných aplikací v praxi, již v 80. letech minulého století se uplatnily fuzzy regulátory ve strojírenství, stavebnictví, dopravě a elektrotechnice (např. ve vagónech metra, ledničkách, pračkách, i pro opravu Hubbleova teleskopu). Pomocí fuzzy teorie lze řídící procesy optimalizovat a automatizovat (Novák \& Knybel, 2005). Počátkem 21. století se objevily další aplikace v oborech jako ekonomie, bankovnictví a personální logistika, v nichž je potřebné, aby systém plynule reagoval a vybral nejvhodnější variantu podle několika hledisek. Tento př́stup je označován jako vícekriteriální hodnocení variant (Talašová, 2003; Shin \& Wang, 2010; Zio, Baraldi, \& Popescu, 2008).

Fuzzy teorie byla vytvořena k modelování nejistoty a neostrostí (nepřesností) hovorových popisů a vychází principiálně z předpokladu, že lidské myšlení a vytváření pojmů není nutno modelovat pouze pomocí přesných matematických pravidel a kvantitativního hodnocení (Klett, 1995). Zatímco základními pojmy v klasické teorii množin jsou pojmy „třída“ a „být prvkem“ (lze jednoznačně určit, zda prvek do dané množiny patří nebo nepatří), základním pojmem fuzzy teorie je pojem fuzzy množina, která připouští mimo úplnou nebo žádnou př́islušnost prvku k množině také př́íslušnost částečnou. Prvek tedy může do množiny patřit s určitou mírou, kterou nazýváme stupeň př́slušnosti. Funkci, která každému prvku univerza přiřadí stupeň př́slušnosti, nazýváme funkce př́íslušnosti. Za stupeň př́́slušnosti se uvažuje reálné číslo z intervalu $<0,1>$, což prakticky znamená, že máme na vyjádření příslušnosti prvku $\mathrm{k}$ množině nekonečně mnoho hodnot $\mathrm{z}$ intervalu $<0,1>$ (Dynda \& Medek, in Zháněl, 2005; Novák, 1990; Půlpán, 1992, aj.). Na rozdíl od aristotelovské dvouhodnotové logiky jsou fuzzy množiny obecně nekonečně hodnotovou logikou a lze je zobrazit graficky pomocí tzv. funkcí příslušnosti. Nejčastěji používanými funkcemi jsou po částech lineární funkce typu $\Gamma, \mathrm{L}, \Pi$ (Dynda \& Medek, in Zháněl, 2005).

\section{Praktické aplikace fuzzy teorie ve sportu}

V devadesátých letech minulého století se aplikace fuzzy teorie objevily i v oblasti sportu. Jak uvádějí Zháněl, Lehnert a Černošek (2006), jednalo se například posuzování interakce útoku a obrany v házené, o učení jízdě na kole, analýzu diagnostických dat v rychlobruslení, v lyžování a ve sportovních hrách, dále o analýzu cviků v rockenrollové akrobacii a v gymnastice. Aplikace fuzzy teorie v diagnostice výkonnostních předpokladů v tenise a v talentových přijímacích zkouškách na VŠ řešili autoři Zháněl, Leist, Kadlčíková a Talašová (1999a, 1999b). Problematikou uplatnění fuzzy teorie při identifikaci talentu se zabývali Rogujl, Papić a Čavala (2009), kteří hledali talenty pro různé sporty na základě morfologické charakteristiky. Bottoni, Gianfelici, Tamburri a Faina (2011) se zaměřili na identifikaci důležitých faktorů při výběru mladých talentů do 14 let v olympijském triatlonu. Papić, Rogujl a Pleština $(2008,2011)$ vytvořili expertní systém „Sport Talent“ pro identifikaci talentů ve věku od 6 do 18 let pro 14 různých sportů (gymnastika, atletika, basketbal, volejbal, tenis a další). Jedná se o první expertní systém, který byl vytvořen pro tento účel s využitím fuzzy logiky a internetu. Martinez, Ko a Martinez (2010) využili fuzzy logiku pro vyhodnocení kvality služeb ve fitness centru pomocí dotazníku; jednalo se o vůbec první aplikaci ve sportovním managementu a marketingu. Talašová (2003) uvádí př́íklad využití fuzzy teorie při diagnostice výkonnostních předpokladů v tenise pomocí softwaru NEFRIT (Nefrit-TENIS, 2000).

Uvedená syntéza poznatků ukázala, že aplikace fuzzy teorie v oblasti diagnostiky pohybových činností je poměrné častá, náš př́spěvek je věnován možnostem využití fuzzy množin $\mathrm{k}$ analýze dat získaných prostřednictvím testové baterie TENDIAG1 a k hodnocení úrovně výkonnostních předpokladů v tenise. Navazujeme na obdobné publikace z dřivějších let (Zháněl, Leist, Kadlčíková, \& Talašová, 1999a, 1999b; Zháněl, Kadlčíková, \& Cibulková 2001; Zháněl, 2005; Zháněl, Lehnert, \& Černošek, 2006).

\section{Výzkumná otázka}

Jak lze využít fuzzy teorii při hodnocení výzkumných dat získaných prostřednictvím testové baterie TENDIAG1?

\section{Cíle výzkumu:}

1) zkonstruovat vhodné funkce př́slušnosti pro hodnocení jednotlivých subtestů testové baterie TENDIAG1,

2) expertně stanovit hodnoty hraničních bodů pro konkrétní věkovou kategorii, 
3) zvolit vhodný typ agregace dílčích výsledků.

\section{Metodika}

Z hlediska výzkumné metodologie se jedná o metodologickou studii, která zkoumá nové př́stupy (metody) a jejich potenciální přednosti proti současným př́stupům (metodám). Jedná se o kvantitativní výzkum analytického charakteru, který je typický shromažd’ováním určité množiny dat nebo se provádějí studie s cílem rozpoznat a vysvětlit principy, které mohou řídit určitá jednání a akce (Hendl, 2008).

\section{Zkoumaná populace}

Výzkumný soubor pro konstrukci funkcí příslušnosti tvořili tenisté ve věku 11-12 let (n=187), kteří se zúčastnili diagnostiky pomocí testové baterie TENDIAG1 v letech 2000 - 2010. Tento výzkumný soubor lze označit jako záměrný výběr, sledovaní tenisté patřili mezi přední české hráče (členové tenisových středisek). Výsledky hráčů $\mathrm{v}$ jednotlivých testech byly využity $\mathrm{k}$ výpočtu hraničních bodů funkcí př́islušnosti. Pro demonstraci způsobu hodnocení pomocí fuzzy přistupu u konkrétních hráčủ bylo náhodně vybráno 25 tenistů.

\section{Organizace výzkumu}

Pro realizaci výzkumného záměru byla využita výzkumná data získaná prostřednictvím testové baterie TENDIAG1, testování probíhá pomocí jednotné metodiky $\mathrm{v}$ tenisových halách pomocí proškolených a zacvičených osob. Sběr dat probíhá dvakrát ročně v rámci projektu Českého tenisového svazu „Komplexní diagnostika $v$ tenise " $u$ hráčů a hráček zařazených do tréninkových středisek a u reprezentačních výběrů.

Testová baterie TENDIAG1 zahrnuje měření základních somatických charakteristik ( 3 položky) a testování úrovně kondičních (3 položky) a koordinačních výkonnostních předpokladů (3 položky), a to jak pomocí tzv. terénních motorických testů, tak i s využitím testů laboratorních, u nichž vyžití sofístikovaných diagnostických přístrojů umožňuje přesnější posouzení některých výkonnostních předpokladů tenistů. Názvy jednotlivých položek (běžecká rychlost, střednědobá vytrvalost, rychlost reakce rukou a nohou atd.) byly převzaty z publikované testové baterie TENDIAG1 (Zháněl et al., 2000). Rychlost reakce rukou i nohou byla zjišt’ována pomocí software a hardware Fitronic a měřena v sekundách. Rychlost se z fyzikálního hlediska vyjadřuje v $\mathrm{m} / \mathrm{s}$, ale z hlediska teorie motorických konstruktů je v odborné literatuře (např. Měkota \& Novosad, 2005, Zháněl, 2005) pojem rychlost chápán jako motorická schopnost (akční i reakční), tedy jako dispozice člověka k rychlému pohybovému jednání, jako schopnost vykonat pohybový úkol v co nejkratším čase (měřeno v sekundách). Proto v antropomotorice a sportovním tréninku jsou používány pojmy „rychlost reakce“, „,sprinterská rychlost“, „běžecká rychlost“" atd. Položky $1-3$ (somatické charakteristiky) mají pouze informativní charakter, nejsou bodově hodnoceny a nejsou součástí celkového skóre testové baterie (Zháněl, Lehnert, \& Černošek, 2006).

\section{Analýza dat}

Soubor naměřených údajů představují data metrická (věk, tělesná váha a výška, BMI, síla ruky, počet správných provedení, doba reakce), jelikož většinou jde o fyzikální veličiny. Zbytek tvoří bezrozměrné veličiny indexového typu, které také patří mezi metrická data. Pro každou věkovou kategorii bylo provedeno ověření normality rozložení četností (Kolmogorov-Smirnov a Lillieforsův test), což umožňuje užití parametrických statistických metod. Výzkumná data byla zpracována pomocí software TENPROG, MS EXCEL, STATISTIKA.

\section{Výsledky a diskuze}

Na základě literární rešerše a expertního posouzení jsme nejprve zvolili funkce příslušnosti (grafické znázornění fuzzy množin) pro jednotlivé subtesty testové baterie TENDIAG1. Vycházeli jsme přitom z publikovaných zkušeností s volbou funkcí př́slušnosti pro testovou baterii TENDIAG2 (Zháněl, Leist, Kadlčíková, \& Talašová, 1999a, 1999b).

Vzhledem k expertnímu posouzení pozitivního vlivu tělesné výšky, síly herní ruky a pohyblivosti trupu na herní výkon $\mathrm{v}$ tenise jsme $\mathrm{k}$ hodnocení těchto subtestů použili funkce př́íslušnosti typu $\Gamma$. Pro konstrukci předpisu $\Gamma$ funkce příslušnosti využijeme označení $\mathrm{v}_{\mathrm{i}}$ pro hodnotu výsledku dané testované osoby $\mathrm{v}$ testu číslo $i, a_{i}$ (odpovídá $\bar{x}_{-\mathrm{s}}$ ) pro hodnotu nevyhovujícího výsledku v testu číslo $i, b_{i}$ (odpovídá $\bar{x}+\mathrm{s}$ ) pro hodnotu vyhovujícího výsledku v testu číslo $i$. Přitom každému výsledku $v_{i}$ mezi hodnotami $a_{i}$ a $b_{i}$ je přiřazena hodnota mezi nulou a jedničkou podle funkce. Obecný předpis pro $\Gamma$ funkci př́slušnosti s výše uvedeným značením potom vypadá následovně: 


$$
\mathrm{A}\left(\mathrm{v}_{i}, \mathrm{a}_{i}, \mathrm{~b}_{i}\right)=\left\{\begin{array}{cc}
0 & \text { pro } \mathrm{v}_{i}<\mathrm{a}_{i} \\
\frac{\left(\mathrm{v}_{i}-\mathrm{a}_{i}\right)}{\left(\mathrm{b}_{i}-\mathrm{a}_{i}\right)} & {\text { pro } \mathrm{a}_{i}<\mathrm{v}_{i}<\mathrm{b}_{i}}_{1} \\
1 & \operatorname{pro~}_{i}>\mathrm{a}_{i}
\end{array}\right.
$$

Pro hodnocení Body Mass Indexu (BMI) jsme zvolili funkci př́slušnosti typu П. Tato funkce nejlépe odpovídá skutečnosti, že optimální hodnoty BMI se pohybují v určitém intervalu. Tento interval vychází ze studií o rozdělení BMI pro běžnou populaci; pro tenisty však musel být upraven, nebot' se jedná o specializovanou skupinu sportovců adaptovanou na jednostrannou zátěž. K úpravě intervalu BMI pro tenisty jsme použili data získaná při měření tenistů a tenistek v rámci testování pomocí baterie TENDIAG1. Pro konstrukci předpisu $\Pi$ funkce př́íslušnosti využijeme stejného označení $v_{i}$ pro hodnotu výsledku dané testované osoby v testu číslo $i$, dále pak $a_{i}$ (odpovídá $\bar{x}_{-}$s) pro první hodnotu nevyhovujícího výsledku v testu číslo $i ; b_{i}$ (odpovídá $\bar{x}_{-} 0,5 \mathrm{~s}$ ) a $c_{i}$ (odpovídá $\bar{x}_{+} 0,5 \mathrm{~s}$ ) pro ohraničení intervalu vyhovujících výsledků $\mathrm{v}$ testu číslo $i ; d_{i}$ (odpovídá $\bar{x}_{+}$s) pro druhou hodnotu nevyhovujícího výsledku v testu číslo $i$. Přitom každému výsledku $v_{\mathrm{i}}$ mezi hodnotami $a_{i}$ a $b_{i}$ je přiřazena hodnota mezi nulou a jedničkou podle funkce $\left(v_{i}-a_{i}\right) /(b i-a i)$, každému výsledku $v_{i}$ mezi hodnotami $c i$ a $d_{i}$ je také přiřazena hodnota mezi nulou a jedničkou, a to podle funkce $\left(d_{i}-v_{i}\right) /\left(d_{i}-c_{i}\right)$. Protože rozdíl mezi hodnotami $a_{i}, b_{i}$ i mezi hodnotami $c_{i}, d_{i}$ je půl směrodatné odchylky, je zřejmé, že jmenovatelé obou zlomků jsou si rovny. Obecný předpis pro П funkci příslušnosti potom vypadá

$$
\mathrm{A}\left(\mathrm{v}_{i}, \mathrm{a}_{i}, \mathrm{~b}_{i}, \mathrm{c}_{i}, \mathrm{~d}_{i}\right)=\left\{\begin{array}{cl}
\frac{\left(\mathrm{v}_{i}-\mathrm{a}_{i}\right)}{\left(\mathrm{b}_{i}-\mathrm{a}_{i}\right)} & \text { pro } \mathrm{v}_{i}<\mathrm{a}_{i} \\
1 & \text { pro } \mathrm{a}_{i}<\mathrm{v}_{i}<\mathrm{b}_{i}>\mathrm{v}_{i}>\mathrm{c}_{i} \\
\frac{\left(\mathrm{d}_{i}-\mathrm{c}_{i}\right)}{\left(\mathrm{d}_{i}-\mathrm{v}_{i}\right)} & \text { pro } \mathrm{c}_{i}>\mathrm{v}_{i}>\mathrm{d}_{i} \\
0 & \text { pro } \mathrm{v}_{i}>\mathrm{d}_{i}
\end{array}\right.
$$

takto:

Pro zbývající subtesty (pohyblivost v ramenních kloubech, běžecká rychlost, běžecká vytrvalost, rychlost reakce rukou a rychlost reakce nohou) jsme použili funkci př́slušnosti typu L, nebot' menší zjištěná hodnota znamená lepší výsledek hodnocení. Při konstrukci norem pro jednotlivé kategorie postupovali tak, že odečtemeli od průměrné hodnoty jednu směrodatnou odchylku ( $\bar{x}_{-}$s), dostaneme nejvyšší hodnotu výsledku absolutně vyhovujícího dané fuzzy množině. Jde tedy o nejvyšší možnou hodnotu výsledku, které je ještě přiřazena jednička. Každé hodnotě výsledku patřícího do otevřeného intervalu ( $\bar{x}_{-} \mathrm{s}, \bar{x}+\mathrm{s}$ ) je opět přiřazena hodnota mezi jedničkou a nulou. Jestliže naopak přičteme k průměru jednu směrodatnou odchylku $(\bar{x}+\mathrm{s})$, dostaneme nejnižší absolutně nevyhovující hodnotu výsledku. To znamená, že každému výsledku, který je roven nebo vyšší než $\bar{x}+\mathrm{s}$, přiřadíme nulu.

Obecný předpis pro L funkci př́slušnosti pak vypadá následovně:

$$
\mathrm{A}\left(\mathrm{v}_{i}, \mathrm{~d}_{i}, \mathrm{c}_{i}\right)=\left\{\begin{array}{cl}
1 & \operatorname{pro~}_{i}<\mathrm{c}_{i} \\
\frac{\left(\mathrm{d}_{i}-\mathrm{v}_{i}\right)}{\left(\mathrm{d}_{i}-\mathrm{c}_{i}\right)} & {\operatorname{pro~} \mathrm{c}_{i}<\mathrm{v}_{i}<\mathrm{d}_{i}}_{0} \\
0 & \operatorname{pro~}_{i}>\mathrm{d}_{i}
\end{array}\right.
$$


Pro přehlednost uvádíme v Tabulce 1 celkový přehled jednotlivých položek testové baterie TENDIAG1 a k nim přiřazené funkce př́íslušnosti.

Tab. 1. TENDIAG1 a funkce príslušnosti

\begin{tabular}{|c|l|c|}
\hline & Položky & Funkce př́́slušnosti \\
\hline 1. & Tělesná vy̌ška & $\Gamma$ \\
\hline 2. & Body Mass Index & $\Pi$ \\
\hline 3. & Pohyblivost (v ramenních kloubech) & $\mathrm{L}$ \\
\hline 4. & Síla herní ruky & $\Gamma$ \\
\hline 5. & Rychlost (b̌̌žecká) & $\mathrm{L}$ \\
\hline 6. & Vytrvalost (střednědobá) & $\mathrm{L}$ \\
\hline 7. & Pohyblivost trupu & $\Gamma$ \\
\hline 8. & Rychlost reakce (ruka) & $\mathrm{L}$ \\
\hline 9. & Rychlost reakce (noha) & $\mathrm{L}$ \\
\hline
\end{tabular}

Jak již bylo uvedeno, somatické charakteristiky (položky 1-3) mají pouze informativní charakter a nejsou součástí celkového skóre testové baterie. Na základě formulace předpisů funkcí př́slušnosti $\Gamma$, L, П pro jednotlivé subtesty jsme vypočítali stupně př́íslušnosti u všech testovaných osob v každé z položek testové baterie. Hodnotám rovným nebo menším než $\bar{x}-s$ (testy č. 4,7 ), resp. $\bar{x}+s$ (testy č. 5, 6, 8, 9) jsme automaticky prriřadili stupeň př́slušnosti nula, tj. nepatří do fuzzy množiny „výborný výsledek v daném testu“. Hodnotám rovným nebo větším než $\bar{x}+s$ (testy č. 4,7 ), resp. $\bar{x}-s$ (testy č. $5,6,8,9$ ) jsme automaticky přiřadili stupeň prŕslušnosti jedna, tj. patří úplně do fuzzy množiny „,ýborný výsledek v daném testu“. Stupně př́slušnosti naměřných hodnot ležících mezi $\bar{x}-s$ a $\bar{x}+s$ jsme vypočítali pomocí předpisu daného odpovídající funkcí příslušnosti. Tyto výsledky patří do fuzzy množiny „výborný výsledek v daném testu“ částečně a jsou tím více vyhovující, čím více se jejich stupeň příslušnosti blíží jedničce.

Nejčastěji vyskytující se funkcí př́slušnosti byla funkce typu L, její průběh a hraniční hodnoty uvádíme jako př́íklad pro položku „běžecká rychlost“ na Obrázku 1. Funkce přiřazuje výsledným časům až do 14,07 s hodnotu 1; potom se hodnocení řídí funkcí $(15,37$ - x)/1,3; výsledky horší než 15,37 s jsou ohodnoceny nulou.

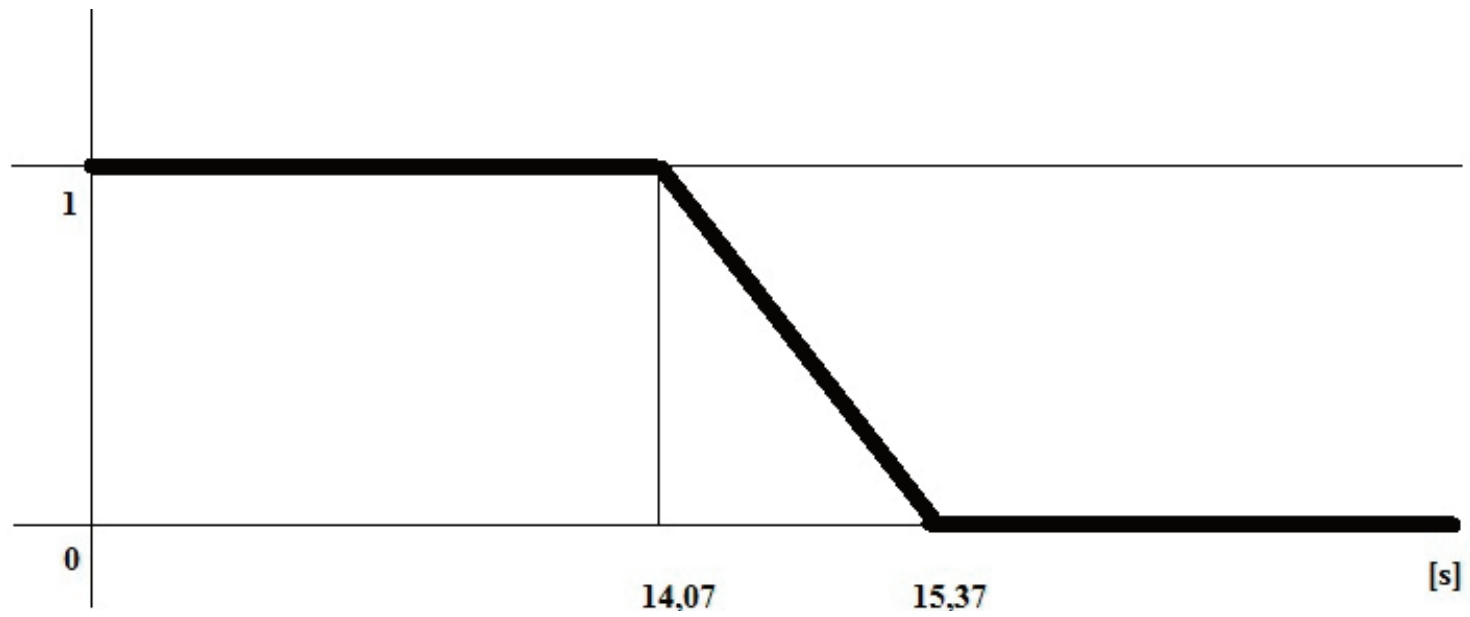

Obr. 1. Funkce př́slušnosti typu L pro hodnoceni běžecké rychlosti 
V Tabulce 2 jsou prezentovány na př́kladu náhodně vybraných probandů (n=25) z věkové kategorie 11-12 let jak výsledky jejich hodnocení v tzv. stupních př́islušnosti (grade of membership) v jednotlivých subtestech získaných pomocí funkcí příslušnosti (sloupce SHR, BR, SV, RRR, RRN, PT), tak i celkové výsledky získané pomocí agregace dílčích výsledků (sloupec AGR).

Tab. 2. Výsledky hodnoceni testové baterie TENDIA1 pomocí fuzzy hodnoticich funkcí

\begin{tabular}{|c|c|c|c|c|c|c|c|c|}
\hline P & Věk[r] & SHR & BR & SV & RRR & RRN & PT & AGR \\
\hline 1 & 11,8 & 0,2 & 0,6 & 0,6 & 0,1 & 1,0 & 0,1 & 0,43 \\
\hline 2 & 11,8 & 0,2 & 0,0 & 0,2 & 0,5 & 0,6 & 0,1 & 0,27 \\
\hline 3 & 11,8 & 0,6 & 0,8 & 0,6 & 0,0 & 0,7 & 0,4 & 0,52 \\
\hline 4 & 11,9 & 0,4 & 0,7 & 0,6 & 0,4 & 1,0 & 0,1 & 0,54 \\
\hline 5 & 11,9 & 0,6 & 0,7 & 0,8 & 0,2 & 0,9 & 0,3 & 0,58 \\
\hline 6 & 11,9 & 1,0 & 0,4 & 0,5 & 1,0 & 0,9 & 0,4 & 0,70 \\
\hline 7 & 11,9 & 0,0 & 0,0 & 0,0 & 0,0 & 0,0 & 0,0 & 0,00 \\
\hline 8 & 11,9 & 0,2 & 1,0 & 1,0 & 1,0 & 0,5 & 0,6 & 0,71 \\
\hline 9 & 11,9 & 1,0 & 0,1 & 0,3 & 0,0 & 0,1 & 0,0 & 0,24 \\
\hline 10 & 12,0 & 0,7 & 0,4 & 0,5 & 0,4 & 1,0 & 0,3 & 0,55 \\
\hline 11 & 12,0 & 0,4 & 0,6 & 0,5 & 1,0 & 0,6 & 0,4 & 0,58 \\
\hline 12 & 12,0 & 0,4 & 0,7 & 0,6 & 0,9 & 1,0 & 0,0 & 0,59 \\
\hline 13 & 12,0 & 0,6 & 1,0 & 1,0 & 1,0 & 0,5 & 0,6 & 0,78 \\
\hline 14 & 12,0 & 0,9 & 0,7 & 0,6 & 0,7 & 0,3 & 0,0 & 0,52 \\
\hline 15 & 12,0 & 0,3 & 1,0 & 0,7 & 0,9 & 0,4 & 0,6 & 0,65 \\
\hline 16 & 12,1 & 0,2 & 0,9 & 0,6 & 0,3 & 0,8 & 0,7 & 0,59 \\
\hline 17 & 12,1 & 0,1 & 0,6 & 0,8 & 0,0 & 0,2 & 1,0 & 0,45 \\
\hline 18 & 12,1 & 0,9 & 0,3 & 0,5 & 0,6 & 0,4 & 0,7 & 0,58 \\
\hline 19 & 12,1 & 0,6 & 0,2 & 0,5 & 0,5 & 0,0 & 0,0 & 0,29 \\
\hline 20 & 12,2 & 0,0 & 0,8 & 0,9 & 1,0 & 1,0 & 0,3 & 0,66 \\
\hline 21 & 12,2 & 0,7 & 1,0 & 0,5 & 0,4 & 0,8 & 0,6 & 0,67 \\
\hline 22 & 12,2 & 0,8 & 0,8 & 0,6 & 1,0 & 1,0 & 1,0 & 0,86 \\
\hline 23 & 12,2 & 0,2 & 0,4 & 0,5 & 0,2 & 1,0 & 0,7 & 0,50 \\
\hline 24 & 12,2 & 0,5 & 0,1 & 0,5 & 0,2 & 0,6 & 0,6 & 0,40 \\
\hline 25 & 12,2 & 1,0 & 1,0 & 0,7 & 0,8 & 0,7 & 1,0 & 0,87 \\
\hline
\end{tabular}

Vysvětlivky:

$\mathrm{P}$ - proband

SHR - síla herní ruky

BR - běžecká rychlost

SV - střednědobá vytrvalost
RRR - reakční čas rukou

RRN - reakční čas nohou

$\mathrm{PT}$ - pohyblivost trupu

AGR - výsledná agregace

Pro výpočet celkového skóre hráčů v testové baterii TENDIAG1 jsme použili metodu agregace dílčích výsledků pomocí aritmetického průměru, kdy každý výsledek má stejnou váhu. Čím více se výsledek agregace blíží číslu 1, tím je výsledné hodnocení lepší („,výborný výsledek“).

Stávající hodnocení dílčích i celkových výsledků jednotlivých hráčů v testové baterii TENDIAG1 je založeného na principu konstrukce třístupňové normy a umožňuje tedy pouze „ostré“ hodnocení (v jednotlivých testech 0-3 body, celkové hodnocení výsledku testové baterie $0-12$ bodů). Oproti tomu umožňuje hodnocení založené na teorii fuzzy logiky kontinuální (a tedy mnohem jemnější) hodnocení v intervalu $<0,1>$. 
Z Tabulky 2 vyplývá, že agregované výsledky jednotlivých hráčů se pohybovaly v rozmezí 0,0 až 0,86 , což je rozpětí téměř celé škály z intervalu $<0,1>$. Nejlepšího agregovaného výsledku dosáhli hráči č. 22 a č. 25 , kteří shodně získali výsledné hodnocení 0,86 . Nejhoršího výsledku dosáhl hráč č. 7 , který ze všech hodnocených položek baterie získal hodnocení 0 .

Prezentovaný způsob vyhodnocení ukazuje možnosti využití fuzzy teorie při analýze dat, která odstraňuje pomocí po částech lineárních funkcí příslušnosti skokový průběh klasického pravděpodobnostního přistupu. Teorie fuzzy množin nabízí tedy kvalitativně jemnější možnosti vyhodnocení výsledků jednotlivých testů i celé testové baterie. $\mathrm{K}$ ještě přesnějšímu hodnocení se nabízejí další sofistikovanější metody agregace, založené na expertním posouzení vah jednotlivých testů z hlediska jejich významu pro finální sportovní výkon. Tyto úvahy však vyžadují hloubkovou analýzy struktury sportovního výkonu v daném sportu a konzultace s tenisovými experty.

\section{ZÁVĚRY}

V předložené práci jsme se zaměřili na prezentaci možností hodnocení výsledků testové baterie TENDIAG1 na principu fuzzy teorie. Na základě expertního posouzení a využití základních statistických charakteristik souboru tenistů ve věku 11-12 let ( $\mathrm{n}=187)$ jsme zkonstruovali funkce př́íslušnosti k jednotlivým subtestům tak, aby průběh funkcí odpovídal měřené veličině a způsobu hodnocení. Vybrali jsme po částech lineární funkce typu $\Gamma, \mathrm{L}, \Pi$. Navržený algoritmus výpočtu hraničních bodů k jednotlivým typům funkcí vychází ze základních statistických charakteristik (aritmetický průměr, směrodatná odchylka). Pro výpočet celkového skóre hráčů v testové baterii TENDIAG1 byla použita metoda agregace dílčích pomocí aritmetického průměru. V další fázi tvorby metodiky vyhodnocení výsledků testové baterie na principu fuzzy teorie lze uvažovat o sofistikovanější metodě agregace umožňující využití různých vah pro hodnocení výsledků dílčích testů (dle jejich významnosti pro tenis).

\section{LITERATURA}

Bottoni, A., Gianfelici, A., Tamburri, R., \& Faina, M. (2011). Talent selection criteria for olympic distance triatlon. Journal of Human Sport \& Exercise, 6 (2), 293-304.

Filipčič, A., \& Filipčič, T. (2005). The relationship of tennis-specific motor abilities and the competition efficiency of young female tennis players. Kinesiology, 37 (2), 164-172.

Hendl, J. (2008). Kvalitativní výzkum: základní teorie, metody a aplikace. Praha: Portál.

Klett, G. (1995). Einführung in Fuzzy Logic. Bonn: Addison-Wesley.

Martínez, J. A., Ko, Y. J., \& Martínez, L. (2010). An application of fuzzy logic to service quality research: a case of fitness service. Journal of Sport Managment, 24, 502-523.

Měkota, K., \& Novosad, J. (2005). Motorické schopnosti. Olomouc: Univerzita Palackého.

Novák, V. (1990). Fuzzy množiny a jejich aplikace. Praha: Státní nakladatelství technické literatury.

Novák, V., \& Knybel, J. (2005). Fuzzy modelování. Ostrava: Ostravská univerzita v Ostravě.

Papić, V., Rogulj, N., \& Pleština V. (2008). Identification of sport talents using a web-oriented expert system with a fuzzy module. Expert Systems with Applications, 36 (5), 8830-8838.

Papić, V., Rogulj, N., \& Pleština V. (2011). Expert System for Identification of Sport Talents: Idea, Implementation and Results. In P. Vizureanu (Ed.), Expert Systems for Human, Materials and Automation (pp. 3-16). Rijeka: InTech.

Půlpán, Z. (1992). Základy informační analýzy didaktického nebo psychologického experimentu. Hradec Králové: Gaudeamus.

Rogujl, N., Papić, V., \& Čavala, M. (2009). Evaluation Models of Some Morphological Characteristics for Talent Scouting in Sport. Coll. Antropol., 33 (1), 105-110.

Talašová, J. (2003). Fuzzy metody vícekriteriálního hodnocení a rozhodování. Olomouc: Univerzita Palackého. Zadeh, L. A. (1965). Fuzzy-Sets. Inform and Control, 8, 338-353.

Zadeh, L. A. (2008). Is there a need for fuzzy logic? Information Science, 178, 2751-2779.

Zháněl, J. (2005). Diagnostika výkonnostních předpokladi̊ ve sportu (a její praktické aplikace v tenise). Habilitační práce, Univerzita Palackého, Fakulta tělesné kultury, Olomouc.

Zháněl, J., Balaš, J., Trčka, D., \& Shejbal, J. (2000). Diagnostika výkonnostních předpokladů v tenise. Tenis, 11(3), 18-19. 
Zháněl, J., \& Kadlčíková, K. (2001). Diagnostics in tennis. In J. Mester, G. King, H. Strüder, E. Tsolakidis \& A. Osterburg (Eds.), Perspectives and Profiles (pp. 1301). Köln: Sport und Buch Strauss.

Zháněl, J., Kadlčíková, K., \& Cibulková, L. (2001). Evaluation of efficiency based on the principle of fuzzy theory in tennis. In Válková, H., Hanelová, H. (Eds.). Movement and Health (pp. 525-529). Olomouc: Univerzita Palackého.

Zháněl, J., Lehnert, M., \& Černošek, M. (2006). Možnosti uplatnění fuzzy logiky při diagnostice výkonnostních předpokladů ve sportu (na př́kladu tenisu). In Sport a kvalita života (p. 141). Brno: Masarykova univerzita.

Zháněl, J., Leist, K.-H., Kadlčíková, K., \& Talašová, J. (1999a). Fuzzy theory and possibilities of its use in diagnostics of motor performance. In H. Válková \& Z. Hanelová, (Eds.), Sborník př́spěvků z mezinárodní konference Pohyb a zdraví (pp. 572-577). Olomouc: Univerzita Palackého.

Zháněl, J., Leist, K.-H., Kadlčíková, K., \& Talašová, J. (1999b). Possibilities of application of fuzzy sets in evaluation of motor performance. In V. Strojnik \& A. Ušaj (Eds.), Sport Kinetics '99. 6th Scientific Conference „, Theories of Human Motor Performance and their Reflections in Practice“ (pp. 421-424). Ljubljana: University of Ljubljana.

Zio, E., Baraldi, P., \& Popescu, C. I. (2008). A fuzzy decision tree for fault classification. Risk Analysis, 28(1), 49-67. 